\title{
A Multicriteria Decision Making and Fuzzy-AHP Approach for Formulating Strategy to Develop Organic Agriculture in Bengkulu Province, Indonesia
}

\author{
Arief Firdaus $^{1}$, Teguh Adiprasetyo ${ }^{1, *}$ Hery Suhartoyo $^{1}$ \\ ${ }^{I}$ Natural Resources Management Study Program of Agriculture Faculty, Bengkulu University, Bengkulu, Indonesia \\ "Corresponding author. Email: teguhadi@yahoo.com
}

\begin{abstract}
Strategy formulation was conducted to develop organic agriculture in Bengkulu Province. This research used multi-criteria decision-making tools which were analytical hierarchy process (AHP) and strength-weaknessopportunity-threat (SWOT) analysis to generate alternative strategies. Then, fuzzy analytical hierarchy process (fuzzy-AHP) was utilized to choose the best strategy for developing organic agriculture in Bengkulu Province. The results identified five strength factors, 16 weakness factors, eight opportunity factors and seven threat factors. The evaluation of internal and external factors led to the internal factor value of 2.26 and the external factor value of 2.54. This result placed the current condition of organic agriculture in the position of weakness-opportunity (WO) quadrant. The fuzzy-AHP analysis ranked the strategies, consecutively 1) strategy of developing an export-oriented competitive organic product, 2) supporting the production and marketing of organic products, and 3) developing community supported organic agriculture.
\end{abstract}

Keywords: fuzzy-AHP, strategy, organic agriculture

\section{INTRODUCTION}

Agriculture is a major source of livelihood in Indonesia. Agriculture sector contributes the Indonesian national economy accounting for $14.4 \%$ of the gross domestic product involving $34.4 \%$ of total employment. The productivity of food crops is increasing year after year [1]. The use of chemical inputs in agriculture practice has generated growth in productivity. However, this method also creates a heavy dependence of farmers on chemical fertilizers and pesticides. This intensive production farming system also triggers natural resource degradation. The dependence of conventional farming on chemical inputs has negative impacts on the environment and human health [2], [3]. The effects of conventional farming on the environment, such as eutrophication, decreasing soil biodiversity and biological fertility, in turn, may impede agricultural productivity itself [2]. The strong evidence of diminishing returns on harvested agricultural products is factual, despite the increases of chemical fertilizers and pesticides applied [4]. These pieces of evidence are lessening confidence that these high input technologies will deliver national food security in the next decades sustainably. Because of these problems, alternative technological approaches of farming practices, such as organic farming are being promoted. It is understood that organic farming has the capability to take care of the problems caused by conventional agriculture. Along with the benefits of organic farming has on the environment and quality of food, it also greatly helps farmers to become self-sufficient in requiring for agricultural inputs and reduce costs [5].

According to [6] and [7], organic agriculture is defined as an approach toward sustainable agricultural production system by applying integrated, socially accepted, environmentally sound and economically feasible farming practice. Organic production management system avoids the use of synthetic fertilizers, pesticides, and genetically modified organisms. The objective of organic agriculture is basically to protect the long-term soil fertility by maintaining soil organic matter content, encouraging soil biological activity and careful mechanical intervention. Organic farming enhances biodiversity, biological cycles, and microbial activities and thus will develop healthy agroecosystem.

Reference [8] defines organic agriculture as a farming method based on the principles of health, ecology, fairness, and care. Organic farming can play a significant role towards sustainable utilization of resources in food production with less pollution and contributes to food availability [9]. According to [10], organic farming also supports sustainable food security in term of food availability, food access, stability, and utilization. Reference [11] also notes that organic agriculture can generate significant benefits including economic potential. Economic potential generated from organic farming derives from using local resources, avoiding the use of chemicals to raise yields and increasing income from a 
premium price of organic products. This economic benefit of organic farming eventually may improve livelihoods of farmers [12].

Although several studies indicate that organic farming is more profitable than conventional farming in the long term, in reality, the conversion of conventional farming to organic farming progress slowly. In Indonesia, total certified organic area in 2014 was 68,605 hectares [13] that are only $0.3 \%$ of total agricultural areas. Therefore, there is a lot of opportunities and challenges in developing organic agriculture in Indonesia. However, some technical, economic and social constraints may hamper for developing organic farming [14]. Reference [15] indicates several barriers to organic farming development, among other productivity, standardization, and certification, production technology, market and other aspects. Efforts have to consider all of the potentials, barriers, and opportunities for advancing the endeavours to develop organic agriculture efficiently. Based on the leverage factors of potentials, barriers, and opportunities in developing organic farming, some alternative strategies can be formulated and selected. Formulation and selection of alternative strategies are a problem of decision making or optimization since it involves value or economic judgments, trade offs, and decisions [16]. Decision making in strategy formulation is challenging tasks since sometimes decision situation is complex, strategic, dynamic, and having long term effects. Then, in this kind of situation, multi-criteria decision making can be applied to formulate a strategy [17]. According to [18], multicriteria decision making will generate a sound and logic decision that can manage trade off effectively. This study is intended to identify factors influencing organic agriculture development, formulate alternative strategies and select the best strategy by employing multi-criteria decision making for developing organic farming in Bengkulu Province.

\section{METHODS}

Data collection were performed through a questionnaire and in-depth interview for expert knowledge acquisition. Respondents of this study were 27 experts consisting of 7 academicians, 13 provincial and regency government officers, and seven organic farmers. The expert survey was employed as the realization of knowledge acquisition process of the expert respondents [19].

Stages of this study were comprised of:

a) Identifying factors influencing the development of organic agriculture through a questionnaire,

b) Weighing factors using analytical hierarchy process (AHP) [20] through a questionnaire,

c) Rating factors and constructing internal-external matrix for determining the position of current condition of organic agriculture,

d) Developing alternative strategies using Strength, Weakness, Opportunity, and Threat (SWOT) analysis [21], e) Ranking and choosing the best strategy utilizing fuzzy analytical hierarchy process [22].

Identifying factors influencing the development of organic agriculture was performed through a questionnaire and interviewing the experts. The candidate factors were differentiated into internal and external categories. Expert assessed the candidate factors and assigned the level of agreement for each candidate factors through a questionnaire. Based on the expert appraisal, factors that most experts agreed were selected as internal and external factors influencing the organic agriculture development.

The selected internal and external factors were weighted using AHP. Analytical Hierarchy Process was performed by pair comparison of each internal and external factor and assigned a value based on Saaty comparison scale, as shown in Table 1. Weight was based on response value of the experts and calculated through matrix manipulation. Detail steps of implementing AHP can be referred to [20] and [17].

Table 1 Saaty comparison scale

\begin{tabular}{|c|l|}
\hline Value & \multicolumn{1}{c|}{ Explanation } \\
\hline 1 & factor A and B are equally important \\
\hline 3 & $\begin{array}{l}\text { factor A is a bit more important than factor } \\
\text { B }\end{array}$ \\
\hline 5 & $\begin{array}{l}\text { factor A is strongly more important than } \\
\text { factor B }\end{array}$ \\
\hline 7 & $\begin{array}{l}\text { factor A is very strongly more important } \\
\text { than factor B }\end{array}$ \\
\hline 9 & $\begin{array}{l}\text { factor A is absolutely more important than } \\
\text { factor B }\end{array}$ \\
\hline $2,4,6$, & $\begin{array}{l}\text { If in doubt between two adjacent values } \\
8\end{array}$ \\
\hline
\end{tabular}

Internal and external matrix was constructed based on selected factors, weight and score of factors. Each of selected internal and external factors were rated based on the influence level of a factor on organic agriculture development. The final score of a factor was weight times rating of a factor. The total score of internal factors and external factors determined the position of the current condition of organic agriculture. The place of the current state can be in quadrant I (Strength-Opportunity), quadrant II (Strength-Threat), quadrant III (Weakness-Opportunity), or quadrant IV (Weakness-Threat). Alternative strategies were developed using SWOT analysis. The detail of strategy development based on SWOT analysis can be referred to [21].

Fuzzy analytical hierarchy process (fuzzy AHP) was employed to rank and select the best alternative strategies. Fuzzy pair comparison was used to judge alternative strategies based on the methods, steps, and calculation developed by [22] with equivalence of linguistic variable to triangular fuzzy number as shown in Table 2. Pair comparison was performed using assessment scale of linguistic expression, as follows: 
a) Just equal (JE) if both elements compared were just equally important,

b) Equally important (EQ) if both elements compared are more or less equally important,

c) Weakly important (WI) if one element was a bit more important than another element,

d) Strongly more important (SI) if one element was more important than another element,

e) Very strongly more important (VS) if one element was more important than another element,

f) More important (AI) if one element was definitely more important than other elements.

Table 2 Equivalence of linguistic variable to triangular fuzzy number

\begin{tabular}{|l|l|l|l|}
\hline No & \multicolumn{1}{|c|}{$\begin{array}{c}\text { Linguistic } \\
\text { Variable }\end{array}$} & TFN & $\begin{array}{l}\text { TFN } \\
\text { Inversion }\end{array}$ \\
\hline 1 & Just equal (JE) & $(1,1,1)$ & $(1,1,1)$ \\
\hline 2 & $\begin{array}{l}\text { Equally important } \\
\text { (EQ) }\end{array}$ & $(1 / 2,1,3 / 2)$ & $(2 / 3,1,2)$ \\
\hline 3 & $\begin{array}{l}\text { Weakly important } \\
\text { (WI) }\end{array}$ & $(1,3 / 2,2)$ & $(1 / 2,2 / 3,1)$ \\
\hline 4 & $\begin{array}{l}\text { Strongly more } \\
\text { important (SI) }\end{array}$ & $(3 / 2,2,5 / 2)$ & $(2 / 5,1 / 2,2 / 3)$ \\
\hline 5 & $\begin{array}{l}\text { Very strongly more } \\
\text { important (VS) }\end{array}$ & $(2,5 / 2,3)$ & $(1 / 3,2 / 5,1 / 2)$ \\
\hline 6 & $\begin{array}{l}\text { Absolutely more } \\
\text { important (AI) }\end{array}$ & $(5 / 2,3,7 / 2)$ & $(2 / 7,1 / 3,2 / 5)$ \\
\hline
\end{tabular}

Expert judgments aggregation was sum up of the fuzzy value of all expert assessment. Summation of expert assessment was completed by geometric averaging the fuzzy value of the expert opinion [17]. The aggregation was done for lower bound, middle and upper bound of fuzzy value from each expert opinion based on the following formula:

$$
\begin{aligned}
& \overline{L B}=\sqrt[n]{\pi_{i=1}^{n} \chi_{b b i}} \\
& \bar{M}=\sqrt[n]{\pi_{i=1}^{n} \chi_{b b t}} \\
& \overline{U B}=\sqrt[n]{\pi_{i=1}^{n} \chi_{b b a}}
\end{aligned}
$$

where:

$\overline{L B}$ : geometric average of lower bound fuzzy value

$\bar{M}$ : geometric average of middle fuzzy value

$\overline{U B}$ : geometric average of upper limit fuzzy value

$\chi_{b b i}$ : lower bound value of the $\mathrm{i}^{\text {th }}$ expert judgment

$\chi_{b t i}$ : the central value of the $i^{\text {th }}$ expert judgment

$\chi_{b a i}$ : the higher value of the $\mathrm{i}^{\text {th }}$ expert judgment

$n$ : number of experts and I: the $\mathrm{i}^{\text {th }}$ expert ( 1 to $n$ )

\section{RESULT AND DISCUSSION}

Identification of internal and external factors came up with 21 internal factors and 15 external factors that influence the development of organic agriculture in Bengkulu Province. Evaluation of the internal factors shows that weakness factors are more dominance than strength factors (Table 3). The prominence weakness factors that may hinder the development of organic agriculture are low level of farmer understanding of organic farming, lack of marketing network of organic products, deficient of government policy to facilitate marketing of organic products, lack of special program to develop organic agriculture at the local/provincial/regency government level, and low availability of programs related or supporting the organic farming practice. While the strength factors include the high awareness that organic products safe for human health and organic agriculture support the sustainability of the environment, the lower cost of the production inputs, and the high availability of natural resources in organic farming practice.

Evaluation of the external factors reveals that opportunity factors are more dominance than threat factors (Table 4). The distinction threat factors that may impede the development of organic agriculture in Bengkulu Province are small opportunity to collaborate with other parties for marketing organic products, limited consumer knowledge on food safety and organic product, and little awareness of people and non-government organization to provide safe and healthy food. While the opportunity factors that exist and may advance organic agriculture development are the high intention of agricultural land conversion to organic farming, the abundance of agriculture input supports to facilitate organic farming development, development of superior organic commodity, and availability of programs in line with organic farming development.

Analysis of Internal-External Matrix shows that the current position for developing organic agriculture in Bengkulu Province in the Weakness-Opportunity quadrant (quadrant III) since the total score of an internal factor and external factor are 2.26 and 2.54 respectively (Figure 1). This position indicates that generic strategy to develop organic agriculture should be 'turnaround' strategy that is harnessing the opportunities while improving the existing weaknesses. Alternative strategies were then developed by synthesizing the weaknesses and opportunities include:

a) Developing export-oriented organic agricultural products (Internal Factor 1,2,3,6,14 and External Factor 13,15),

b) Provisioning certification incentive and cost sharing for farmers (Internal Factor 1,6,16 and External Factor 9,10,14),

c) Developing cross-sectoral integrated organic agriculture (Internal Factor 3,4,5,9,10,11,14,15 and External Factor 9,10,12,14),

d) Building farmer institution and market network (Internal Factor 1,2,3,4,5,7,8,14 and External Factor 10,11,15),

e) Fostering organic community supported agriculture (Internal Factor 1,2,4,6,8,10,11,14 and External Factor 11,12,13,14),

f) Providing organic production and marketing supports (Internal Factor 1,2,3,4,5,7,9,10,11,14,15 and External Factor 9,12,13,14). 
Table 3 Internal Factor Matrix

\begin{tabular}{|c|c|c|c|c|}
\hline No & Internal Factor & Weight & Rating & Score \\
\hline 1 & $\begin{array}{l}\text { Farmer understanding of } \\
\text { organic agriculture }\end{array}$ & 0.2002 & 2 & 0.40 \\
\hline 2 & $\begin{array}{l}\text { Marketing network of organic } \\
\text { products }\end{array}$ & 0.0934 & 2 & 0.19 \\
\hline 3 & $\begin{array}{l}\text { Government policy to facilitate } \\
\text { marketing of organic products }\end{array}$ & 0.0671 & 2 & 0.13 \\
\hline 4 & $\begin{array}{l}\text { Special program to develop } \\
\text { organic agriculture at the } \\
\text { local/provincial/regency } \\
\text { government level }\end{array}$ & 0.0558 & 2 & 0.11 \\
\hline 5 & $\begin{array}{l}\text { Availability of program related } \\
\text { or supporting the organic } \\
\text { farming practice }\end{array}$ & 0.0490 & 2 & 0.10 \\
\hline 6 & $\begin{array}{l}\text { Information for farmer } \\
\text { regarding organic product } \\
\text { certification }\end{array}$ & 0.0387 & 2 & 0.08 \\
\hline 7 & $\begin{array}{l}\text { Availability of capital for } \\
\text { farmer to get education or } \\
\text { training on organic agriculture }\end{array}$ & 0.0362 & 2 & 0.07 \\
\hline 8 & $\begin{array}{l}\text { The number of organic farmer } \\
\text { organization }\end{array}$ & 0.0355 & 2 & 0.07 \\
\hline 9 & $\begin{array}{l}\text { The level of holistic approach } \\
\text { to developing organic } \\
\text { agriculture }\end{array}$ & 0.0319 & 2 & 0.06 \\
\hline 10 & $\begin{array}{l}\text { Access to university as source } \\
\text { of organic agriculture } \\
\text { information }\end{array}$ & 0.0264 & 2 & 0.05 \\
\hline 11 & $\begin{array}{l}\text { The role of non-government } \\
\text { organization }\end{array}$ & 0.0229 & 2 & 0.05 \\
\hline 12 & $\begin{array}{l}\text { Availability of information } \\
\text { technology to support access to } \\
\text { information and } \\
\text { communication }\end{array}$ & 0.0218 & 2 & 0.04 \\
\hline 13 & $\begin{array}{l}\text { Information access to available } \\
\text { knowledge and organic } \\
\text { agriculture technology }\end{array}$ & 0.0214 & 2 & 0.04 \\
\hline 14 & $\begin{array}{l}\text { The level of farmer } \\
\text { organization management }\end{array}$ & 0.0177 & 2 & 0.04 \\
\hline 15 & $\begin{array}{l}\text { Availability of government } \\
\text { support on organic farming } \\
\text { practices }\end{array}$ & 0.0131 & 2 & 0.03 \\
\hline 16 & $\begin{array}{l}\text { Availability of incentive for } \\
\text { farmer to convert to organic } \\
\text { agriculture }\end{array}$ & 0.0100 & 2 & 0.02 \\
\hline 17 & $\begin{array}{l}\text { Organic product safe for human } \\
\text { health }\end{array}$ & 0.0774 & 3 & 0.23 \\
\hline 18 & $\begin{array}{l}\text { The degree of organic } \\
\text { agriculture to support the } \\
\text { sustainability of the } \\
\text { environment }\end{array}$ & 0.0719 & 3 & 0.22 \\
\hline 19 & The cost of agricultural inputs & 0.0422 & 3 & 0.13 \\
\hline 20 & $\begin{array}{l}\text { The degree of availability of } \\
\text { natural resources in supporting } \\
\text { organic farming practice }\end{array}$ & 0.0388 & 3 & 0.12 \\
\hline 21 & $\begin{array}{l}\text { Availability of appropriate } \\
\text { technology related to organic } \\
\text { agriculture }\end{array}$ & 0.0287 & 3 & 0.09 \\
\hline & Total & $\mathbf{1}$ & & 2.26 \\
\hline
\end{tabular}

Table 4 External Factor Matrix

\begin{tabular}{|c|c|c|c|c|}
\hline No & External Factor & Weight & Rating & Score \\
\hline 1 & $\begin{array}{l}\text { Opportunity to collaborate } \\
\text { with other parties for } \\
\text { marketing organic products }\end{array}$ & 0.1378 & 2 & 0.28 \\
\hline 2 & $\begin{array}{l}\text { The level of consumer } \\
\text { knowledge on food safety and } \\
\text { organic product }\end{array}$ & 0.0885 & 2 & 0.18 \\
\hline 3 & $\begin{array}{l}\text { The awareness of people and } \\
\text { non-government organization } \\
\text { to provide safe and healthy } \\
\text { foods }\end{array}$ & 0.0762 & 2 & 0.15 \\
\hline 4 & $\begin{array}{l}\text { The decrease in number, } \\
\text { quality, and continuity of } \\
\text { product through appropriate } \\
\text { technology }\end{array}$ & 0.0515 & 2 & 0.10 \\
\hline 5 & $\begin{array}{l}\text { Government policy on export } \\
\text { import related to competition } \\
\text { with imported organic } \\
\text { products }\end{array}$ & 0.0497 & 2 & 0.10 \\
\hline 6 & $\begin{array}{l}\text { Adoption of local wisdom } \\
\text { which inlines with organic } \\
\text { farming principles }\end{array}$ & 0.0382 & 2 & 0.08 \\
\hline 7 & $\begin{array}{l}\text { The level of local government } \\
\text { funding support to develop } \\
\text { organic agriculture }\end{array}$ & 0.0208 & 2 & 0.04 \\
\hline 8 & $\begin{array}{l}\text { The level of product } \\
\text { development based on organic } \\
\text { agricultural products }\end{array}$ & 0.1312 & 3 & 0.40 \\
\hline 9 & $\begin{array}{l}\text { The intention level of } \\
\text { agricultural land conversion to } \\
\text { organic agriculture }\end{array}$ & 0.1087 & 3 & 0.33 \\
\hline 10 & $\begin{array}{l}\text { National policy related to } \\
\text { organic agriculture } \\
\text { development }\end{array}$ & 0.0870 & 3 & 0.26 \\
\hline 11 & $\begin{array}{l}\text { The level of organic product } \\
\text { demand in the big cities }\end{array}$ & 0.0672 & 3 & 0.20 \\
\hline 12 & $\begin{array}{l}\text { Availability of agriculture } \\
\text { input supports to facilitate } \\
\text { organic agriculture } \\
\text { development }\end{array}$ & 0.0455 & 3 & 0.14 \\
\hline 13 & $\begin{array}{l}\text { Development of superior } \\
\text { organic commodity }\end{array}$ & 0.0414 & 3 & 0.13 \\
\hline 14 & $\begin{array}{l}\text { Availability of programs in } \\
\text { line with organic farming } \\
\text { development }\end{array}$ & 0.0399 & 3 & 0.12 \\
\hline 15 & $\begin{array}{l}\text { Availability of international } \\
\text { market for organic products }\end{array}$ & 0.0163 & 3 & 0.05 \\
\hline & Total & 1 & & 2.54 \\
\hline
\end{tabular}

The strategy of developing export-oriented organic agricultural products is intended to promote organic products that have high sale value and market demand. Therefore, it is expected to facilitate:

a) Product marketing,

b) Export-oriented products are supposed to provide higher returns. The results of this study indicate that the primary driving factor for technology transfer to farmers is the economic factor.

c) Further impacts of the expected number of farmers to understand and adopt the greater organic agriculture, 
d) Research development efforts to produce quality and competitive products growing with the development of the export market,

e) Assist the government in determining the direction of policies, programs, and assistance with focused intervention for the development of superior organic products,

f) Encourage the availability of information about certification for farmers. Export-oriented organic agriculture is expected to promote the availability of information on the certification of international scale and improve management of agricultural producers and managers in marketing their products.

Based on data from [13], the area certified by an international certification body in Indonesia mostly was intended for coffee production. Therefore, the coffee organic agricultural products can be developed in Bengkulu Province. Organic coffee products are mainly intended for export. The alternative strategy of development export-oriented organic coffee products has the prospect to be implemented.

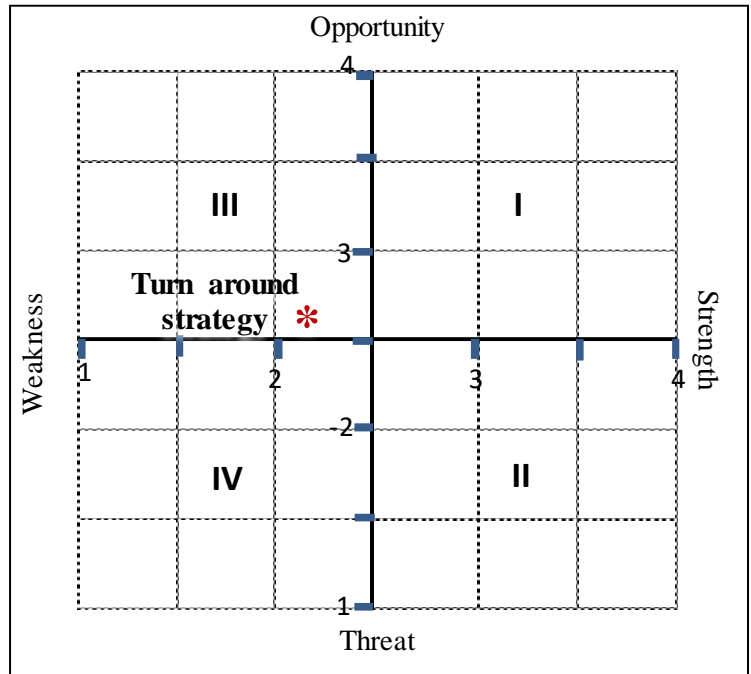

Figure 1 Current position of organic agriculture

A strategy of incentive certification provision and cost sharing is meant to tackle the challenging issue of certification. Certification is one of the challenges of organic farming, especially for small farmers. Certification is an important topic since according to [23], certification is necessary for among others:

a) Protecting consumers from fraud and manipulation and claims of products that are not organic,

b) Protecting producers and organic food products from fraudulent other agricultural products that claim to be organic products,

c) Providing assurance that all stages of production, preparation, storage, transportation, and marketing can be checked and following the standards of organic food products,

d) Harmonization is needed in the regulation of the production system, certification, identification and labelling of organic food products.

Organic products that have internationally recognized certification have most likely be accepted in the local, national or international market. This study revealed weak certification information, the lack of understanding of organic agriculture and the small number of farmers who practice organic farming. The alternative strategy is expected to cover up these weaknesses using the opportunities available, especially for:

a) Encouraging more farmers/farmer groups are converted to organic agriculture,

b) Boosting the availability of access to certification information,

c) Fostering the understanding and adoption of organic farming among farmers, and

d) Facilitating organic product marketing at national and international levels with the quality assurance through certification.

The strategy of organic agriculture integrated cross-sectoral development is expected to handle the weakness of organic agriculture development in Indonesia. One of the factors of the shortcomings of organic agriculture development in Indonesia, particularly in the province of Bengkulu is a partial approach in developing things. Policies tended to focus only on certain aspects, such as cultivation, and less attention given to other aspects. Various agricultural development programs have been widely implemented, such as program utilization of backyard areas, use of livestock manure into organic fertilizer and biogas, animal husbandry and freshwater fish, post-harvest processing program, and a program of economic development of small and medium enterprises. However, these programs implemented sectoral. The programs that exist in the relevant agencies is likely to be used to develop organic agriculture if it can be coordinated and integrated into an integrated model of organic farming development. Furthermore, alternative development strategy of integrated cross-sectoral organic agriculture will improve and help aspects of marketing, mastery of technology, access to finance and institutional strengthening for local governments to cooperate with various parties such as universities and private sectors that have an interest in developing organic agriculture.

Farmer institutional development and marketing strategy is built to utilize:

a) national policy related to organic farming,

b) the availability of programs in line with the development of organic farming, 
c) the international market for organic products is likely to increase.

d) To cover the weaknesses of the number of farmer groups that deal with organic farming, the management of farmer groups, and policies that facilitate the marketing of products.

The strategy of the fostering community supported organic agriculture is intended to utilize the demand for organic products in the city that continue to increase and to overcome the weaknesses. The weaknesses that can be affected are:

a) the organic products marketing network,

b) lack of policy to facilitate the marketing of products,

c) the availability of information technology that supports access to market information and communication.

Providing organic production and marketing supports is the last alternative strategy. This alternative strategy is the utilization for:

a) the availability of agricultural inputs assistance that supports the development of organic agriculture,

b) availability of programs that are in line with the development of organic farming,

c) the international market for organic products is likely to increase.

And to overcome the weaknesses comprises of:

a) low understanding of farmers on organic farming,

b) limited access to the university as a center of information about organic farming,

c) inadequate access to information on the results of organic farming research,

d) limited support to organic farmers by the government.

The alternative strategies then analysed using fuzzyAHP to get their ranking. The first three ranking of the alternative strategies are:

a) Developing export-oriented organic agricultural products,

b) Providing organic production and marketing supports, and

c) Fostering organic community supported agriculture.

\section{CONCLUSION}

The study was conducted to identify factors influencing organic agriculture development, formulate alternative strategies and select the best strategy by employing multi-criteria decision making for developing organic agriculture in Bengkulu Province. Identification of internal and external factors finds 21 internal factors and 15 external factors that influence the development of organic agriculture. Evaluation of the internal factors shows that weakness factors are more dominance than strength elements with the internal factor score of 2.26 . Meanwhile, evaluation of the external factors shows that opportunity factors are more dominance than threat factors with the total score of external factors of 2.54. Analysis of Internal-External Matrix indicates that the current position for developing organic agriculture in Bengkulu Province is in the Weakness-Opportunity quadrant or quadrant III. Alternative strategies developed by synthesizing the weaknesses and existing opportunities include a) developing export-oriented organic agricultural products, b) provisioning certification incentive and cost sharing for farmers, c) developing cross-sectoral integrated organic agriculture, d) building farmer institution and market network, e) fostering organic community supported agriculture, f) providing organic production and marketing supports. The first three consecutive ranking of the alternative strategies are 1) developing export-oriented organic agricultural products, 2) providing organic production and marketing supports, and 3) fostering organic community supported agriculture.

\section{REFERENCES}

[1] BPS, 'Statistical Yearbook of Indonesia 2014', Statistics Indonesia, Jakarta, 2015.

[2] D. S. Thakur, and K. D. Sharma, 'Organic farming for sustainable agriculture and meeting the challenges of food security in the 21st century: an economic analysis', Indian J. Agric. Econ., vol. 60, pp. 205-219, 2005.

[3] N. A. Tiraieyari, A. Hamzah, and B.A. Samah, 'Organic farming and sustainable agriculture in Malaysia: organic farmers' challenges towards adoption', Asian Soc. Sci., vol. 10, pp. 1-7, 2014.

[4] N. E. H. Scialabba, 'Organic agriculture and food security', International Conference on Organic Agriculture and Food Security, 3-5 May 2007, FAO, Italy, 2007.

[5] H. M. Chandrashekar, 'Changing scenario of organic farming in India: an overview', Int. NGO J., vol. 5, pp. 34-39, 2010.

[6] F. P. Carvallo, 'Agriculture, pesticides, food security and food safety', Environ. Sci. Policy, vol. 9, pp. 685-692, 2006.

[7] R. Wood, M. Lenzen, C. Dey, and S. Lundie, 'A comparative study of some environmental impacts of conventional and organic farming in Australia', Agric. Syst., vol. 89, pp. 342-348, 2006.

[8] IFOAM, 'Principles of Organic Agriculture Preamble', 2015, the IFOAM website [Online]. Available: http://www.ifoam.bio/sites/ default/files/poa_english_web.pdf 
[9] S. B. Aher, S. Bhaveshananda, and B. Sengupta, 'Organic agriculture: way towards sustainable development', Int. J. Environ. Sci., vol. 3, pp. 209-216, 2012.

[10] M. Vaarst, 'Organic farming as a development strategy: who are interested and who are not?', $J$. Sustain. Dev., vol. 3, pp. 38-50, 2010.

[11] E. Kerselaers, L. De Cock, L. Lauwers, and G. van Huylenbroeck, 'Modelling farm-level economic potential for conversion to organic farming', Agric. Syst., vol. 94, pp. 671-682, 2005.

[12] M. Bennett, and S. Franzel, 'Can organic and resource-conserving agriculture improve livelihoods? A synthesis', Int. J. Agric. Sustain., vol. 11, pp. 193-215, 2013.

[13] AOI, 'Statistik Pertanian Organik Indonesia', Asosiasi Organik Indonesia, Bogor, 2015.

[14] S. Acs, P. B. M. Berentsen, and R.B.M. Huirne, 'Conversion to organic arable farming in The Netherlands: a dynamic linear programming analysis', Agric. Syst., vol. 94, pp. 405-415, 2007.

[15] D. Rigby, and D. Cáreres, 'Organic farming and the sustainability of agricultural systems', Agric. Syst., vol. 68, pp. 21-40, 2001.

[16] M. Zeleny, 'MCDM: in search of new paradigms', In Y. Shi, S. Wang, G. Kou and J. Wallenius (Eds) 'New state of MCDM in the 21st century Selected papers of the 20th International
Conference on Multiple Criteria Decision Making 2009', Springer, Heidelberg, 2011.

[17] Marimin, 'Teknik dan Aplikasi Pengambilan Keputusan Kriteria Majemuk', Grasindo, Jakarta, 2008.

[18] G. Montibeller, and A. Franco, 'Multi-criteria decision analysis for strategic decision making', In C. Zopounidis, and P.M. Pardolos (Eds), 'Handbook of multicriteria analysis', Springer, Hiedelberg, 2010.

[19] Eryatno, and L. Larasati, 'Ilmu sistem: meningkatkan integrasi dan koordinasi manajemen', Center for System dan Penerbit Guna Widya, Surabaya, 2013.

[20] T. L. Saaty, and L.G. Vargas, 'Models, methods, concepts, and applications of the analytical hierarchy process', Springer, Hiedelberg, 2012.

[21] A. W. Stein, 'Strategic management for public and nonprofit organizations', Marcel Dekker Inc, New York, 2003.

[22] D. Y. Chang, 'Applications of the extent analysis method on fuzzy AHP', Eur. J. Oper. Res., vol. 95, pp. 649-655, 1996.

[23] BSN, 'Sistem pangan organik-SNI 6729:2010', Badan Standardisasi Nasional, Jakarta, 2010. 